Gut, 1966, 7, 307

\title{
A pharmacological study of the motility of the human gastrointestinal tract
}

\author{
ALAN BENNETT AND BRIAN WHITNEY1 \\ From the Department of Surgery, King's College Hospital Medical School, London
}

EDITORIAL SYNOPSIS This is a comprehensive study of the pharmacological responses of strips of isolated human gastrointestinal tract. The results suggest that there is little intrinsic nervous activity' in the stomach and proximal duodenum but there is a dominant cholinergic drive in the distal duodenum and, in particular, in the jejunum. More distally, in the ileum and especially in the colon the dominant influence is the 'intrinsic sympathetic activity'. The authors relate their findings to the functions of different regions of the gastrointestinal tract.

For the full understanding of gastrointestinal motility and its control, studies under appropriate conditions in living animals and patients are essential. In such circumstances, however, it is extremely difficult or impossible to make precise observations on each individual element involved in motility because of the many factors involved at any one time. Experiments on isolated strips of gastrointestinal muscle eliminate many of these variables, and help to provide a foundation on which to build a comprehensive understanding of motility.

Although the pharmacology of the gastrointestinal tract of animals has been extensively studied in vitro, there have been relatively few investigations of human isolated tissue (Graham, 1949; Walder, 1953; Trounce, Deuchar, Kauntze, and Thomas, 1957; Ellis, Kauntze, Nightingale, and Trounce, 1960; Trounce and Nightingale, 1960; Fishlock and Parks, 1963; Gazet and Jarrett, 1964). We have reported results of pharmacological studies of the stomach, jejunum, ileum, and colon in man (Bennett and Whitney, 1966; Whitney, 1965; Bennett, 1965; Bucknell and Whitney, 1964), and now report a study of human isolated duodenum. This completes a preliminary study on the gastrointestinal tract from the stomach to the colon. The results show that different parts of the gut vary in their responses to naturally occurring substances and to drugs. We have attempted to correlate these variations and form a hypothesis of how factors influence motility throughout the alimentary tract. This involves observations on the role of pharmacologically active substances in the bowel wall, on the part played by nervous tissue in motility and peristalsis, and on the function of sphincters.

\footnotetext{
1 Present address: St. George's Hospital, London.
}

\section{METHODS}

Tissue which was macroscopically normal and free from disease was cut from specimens resected at operation and taken to the laboratory in Krebs solution at room temperature. The mucosa and submucosa were usually removed and a strip (approximately $3 \mathrm{~cm}$. long and $2-3 \mathrm{~mm}$. wide) was cut from the muscle layer. It was suspended in an organ bath at $37^{\circ} \mathrm{C}$. containing $\mathrm{Krebs}$ solution aerated with $95 \%$ oxygen and $5 \%$ carbon dioxide. The movements of the tissue were recorded by a lever writing on a smoked drum. The details of the method and the preparation of longitudinal and circular muscle strips were as described by Bucknell and Whitney (1964). The following drugs were used:- Acetylcholine perchlorate, adrenaline bitartrate, noradrenaline bitartrate, isoprenaline sulphate, phenylephrine hydrochloride, 5-hydroxytryptamine creatinine sulphate, histamine acid phosphate, dimethylphenylpiperazinium iodide, nicotine acid tartrate, potassium chloride, hyoscine hydrobromide (cholinergic antagonist), Hydergine, pronethalol hydrochloride, and guanethidine sulphate (adrenergic antagonists), mepyramine maleate (antihistamine), methysergide hydrogen maleate (5-HT antagonist), hexamethonium bromide (ganglion blocker), physostigmine sulphate, and neostigmine methyl sulphate (anticholinesterases). Drug concentrations refer to the base except for Hydergine, pronethalol, guanethidine, and potassium.

\section{RESULTS}

The detailed results obtained with strips of circular and longitudinal muscle from the duodenum are given in Table $I$. The effects of the drugs studied and their sites of action are illustrated in Figure 1.

SPONTANEOUS ACTIVITY Rhythmic spontaneous contractions were uncommon in strips of the first part of the duodenum, but almost always occurred in strips from the second and third parts. 
TABLE I

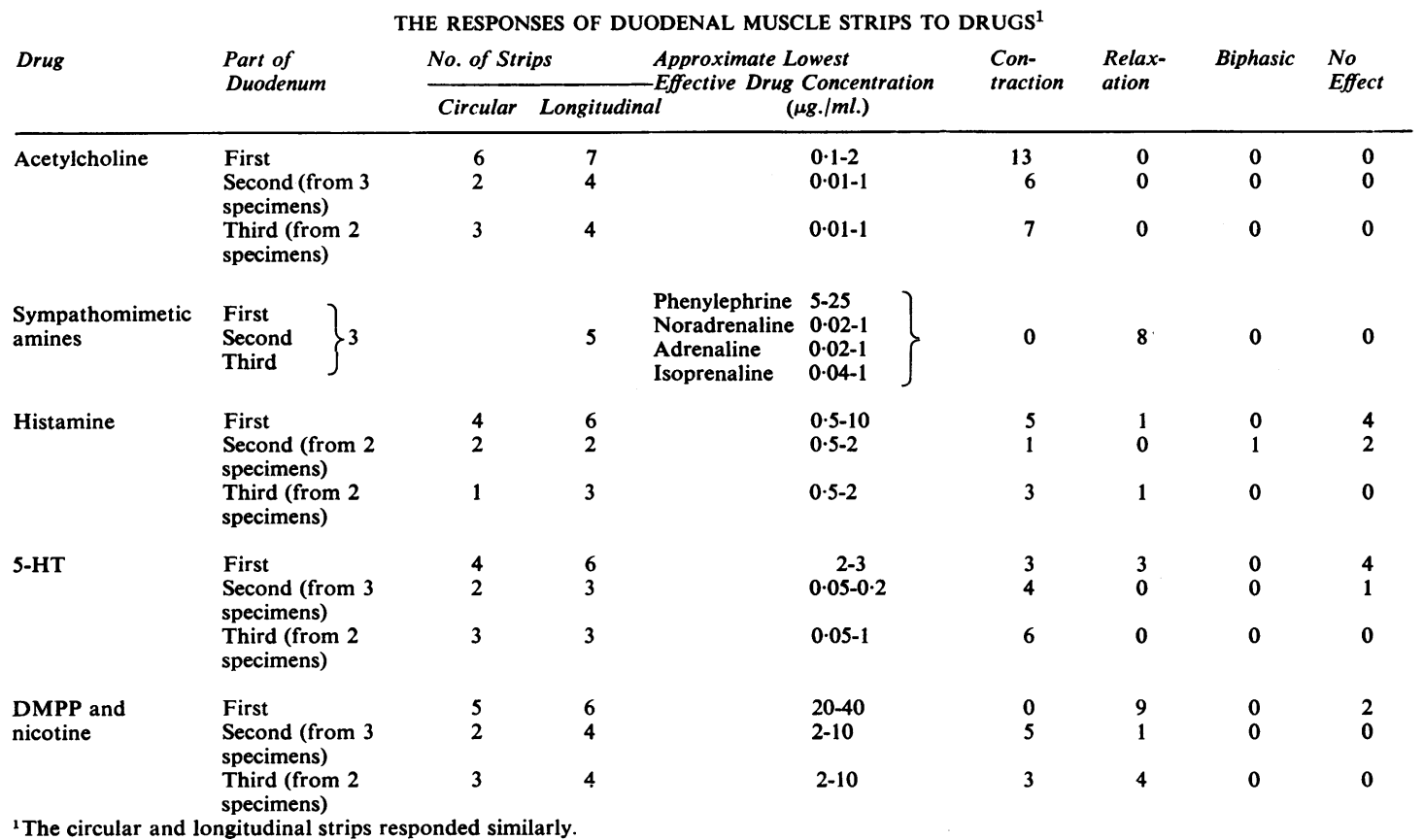

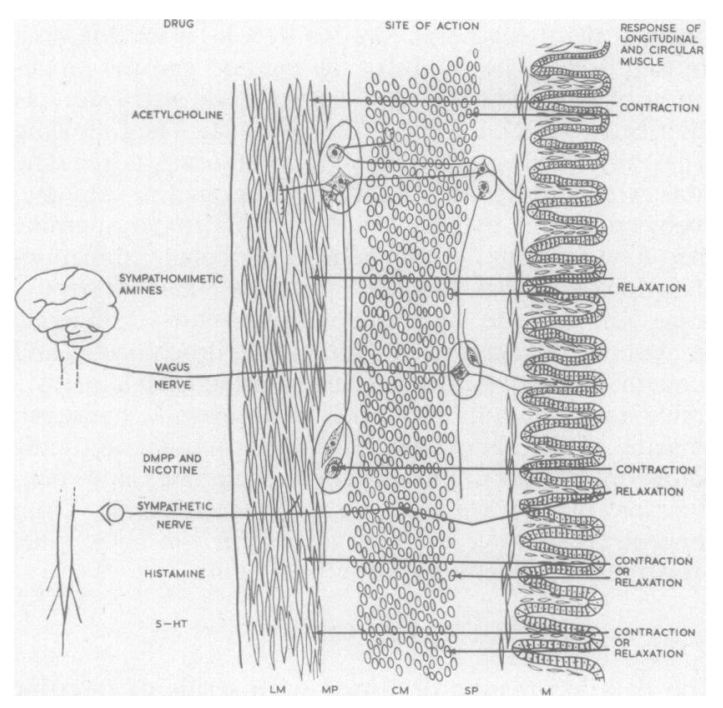

FIG. 1. The action of drugs on the gastrointestinal tract. Acetylcholine, the sympathomimetic amines, histamine and 5-HT, act directly on the muscle. DMPP and nicotine act on nervous tissue. $L M$, longitudinal muscle; $M P$, myenteric plexus; $C M$, circular muscle; SP, submucous plexus; $M$, mucosa; (after C. J. Hill, from Maximow and Bloom, Textbook of Histology, with the kind permission of $W . B$. Saunders Company).
ACETYLCHOLINE Strips from the first part of the duodenum were rather insensitive to acetylcholine and responded with relatively small contractions. In contrast, strips from the second and third parts were more sensitive and generally contracted well (Fig. 2). The contractions were potentiated by eserine $(0 \cdot 1 \mu \mathrm{g} . / \mathrm{ml}$.$) , abolished by hyoscine (0 \cdot 1$ $\mu \mathrm{g} . / \mathrm{ml}$., Figs. 2 and 3 ), and were either unaffected by hexamethonium $(20-40 \mu \mathrm{g} . / \mathrm{ml}$., three experiments), or slightly reduced by it (three experiments; Fig. 3).

SYMPATHOMIMETIC AMINES These drugs inhibited spontaneous activity and relaxed all parts of the duodenum. Often strips from the first part of the duodenum did not have any 'tone' and the inhibitory effects of sympathomimetic amines and other drugs were then demonstrated as a reduced response of the tissue to acetylcholine (Fig. 4) or potassium. Blocking the adrenaline $a$-receptors with Hydergine $(1 \mu \mathrm{g} . / \mathrm{ml}$.) prevented the effect of the $a$-adrenergic stimulant phenylephrine but not the $\beta$-adrenergic stimulant isoprenaline. The adrenaline $\beta$-receptor antagonist pronethalol $(10 \mu \mathrm{g} . / \mathrm{ml}$.) blocked the response to isoprenaline, but not to phenylephrine. Both antagonists together prevented the effect of any of the sympathomimetic amines.

HISTAMINE The effects of histamine varied, and 


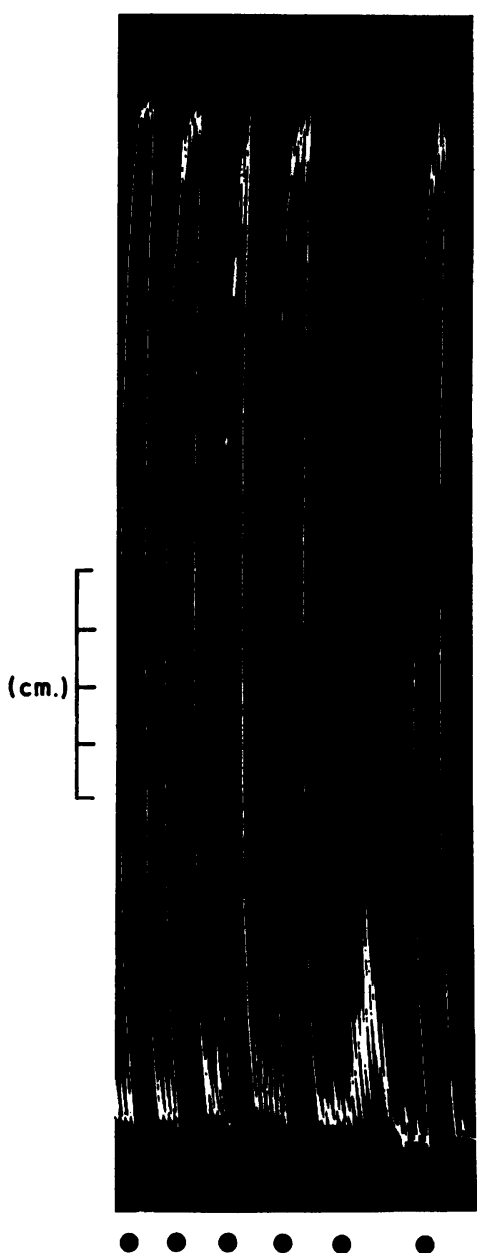

A A H A N A

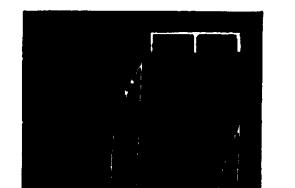

prevented the effects of histamine. The contractions were unaffected by hyoscine $(0 \cdot 1 \mu \mathrm{g} . / \mathrm{ml}$.) and the relaxant responses were unaffected by the adrenergic neurone blocker guanethidine $(10 \mu \mathrm{g} . / \mathrm{ml}$.).

5-HYDROXYTRYPTAMINE (5-HT) The effects of this substance also varied and tachyphylaxis sometimes developed. The first part of the duodenum was rather insensitive to 5-HT; either small contractions, small relaxations, or no response occurred. In contrast, muscle strips from the second and third parts of the duodenum were more sensitive and generally contracted strongly. The contractile (Fig. 3) and relaxant responses to 5-HT were blocked by methysergide. The contractions were unaltered by the ganglion-blocking drug hexamethonium $(20-40 \mu \mathrm{g} . / \mathrm{ml}$., Fig. 3) or by hyoscine $(0 \cdot 1-0 \cdot 5$ $\mu \mathrm{g} . / \mathrm{ml}$.).

DMPP AND NICOTINE The responses varied with these drugs too, and again tachyphylaxis sometimes occurred. Strips of the first part of the duodenum were either relaxed or unaffected by these drugs. No contraction occurred even in the presence of eserine $(0 \cdot 1-0.4 \mu \mathrm{g} . / \mathrm{ml}$.) or neostigmine $(0 \cdot 2-0 \cdot 4$ $\mu \mathrm{g} . / \mathrm{ml}$.) except on one occasion. In this experiment, the first dose of nicotine caused a small contraction of an eserinized strip, but subsequent doses had no effect. Preparations from the second and third parts were more responsive and either contracted (Figs. 2 and 3) or relaxed. Eserine $(0.1 \mu \mathrm{g} . / \mathrm{ml}$.) potentiated the contractions and converted the relaxations of the second and third parts into contractions. Hyoscine $(0.1 \mu \mathrm{g} . / \mathrm{ml}$.) blocked the contractions and unmasked a relaxant effect of DMPP and nicotine (Fig. 2). The adrenergic blocking drugs Hydergine $(1 \mu \mathrm{g} . / \mathrm{ml}$.) and pronethalol $(10 \mu \mathrm{g} . / \mathrm{ml}$.) prevented the relaxations. Both the contractions and the relaxations were blocked by hexamethonium (20-40 $\mu \mathrm{g} . / \mathrm{ml}$., Fig. 3).

COMPARISON OF THE PHARMACOLOGY OF DIFFERENT PARTS OF THE HUMAN GASTROINTESTINAL TRACT The results from this and other studies (Fishlock and Parks, 1963; Bucknell and Whitney, 1964; Whitney, 1965; Fishlock, Parks and Dewell, 1965; Bennett, 1965; Bennett and Whitney, 1966) show that different regions of the gut vary in both their sensitivity and response to drugs. Table II presents these data in a semiquantitative manner.

\section{DISCUSSION}

The motility of the gastrointestinal tract depends on many factors. These include the intrinsic nerve plexuses, the extrinsic autonomic nerves to the gut, and the ability of muscle fibres to respond to stimuli. experiment and the response was biphasic in another. The antihistamine mepyramine (10-100 $\mu \mathrm{g} . / \mathrm{ml}$.) 


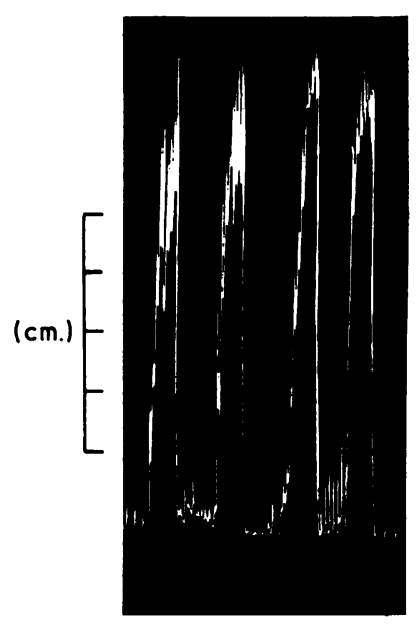

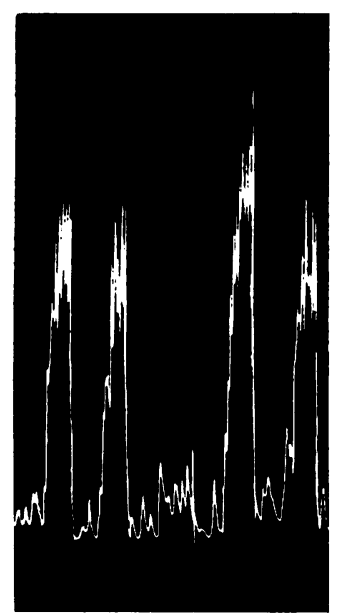

$\begin{array}{rrrr}\bullet & \bullet & \bullet & \bullet \\ H T & A & N & A\end{array}$
1
6
min.

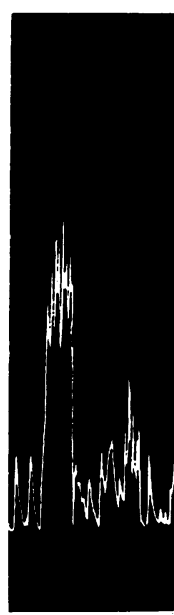

$\begin{array}{ll}\mathrm{A} & \mathrm{N}\end{array}$ 12 min.

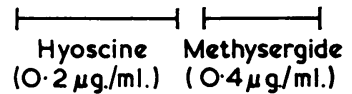

FIG. 3. The responses of a circular muscle strip from the second part of the duodenum to 5-hydroxytryptamine (HT, $0.2 \mu \mathrm{g} . / \mathrm{ml}$.$) , acetylcholine (A, 0 \cdot 1 \mu \mathrm{g} . / \mathrm{ml}$.$) , and nicotine (\mathrm{N}, 20 \mu \mathrm{g} . / \mathrm{ml}$.$) . This tracing also shows ($ a) a reduction of the response to acetylcholine, but not to 5-HT, by hexamethonium (C6), (b) antagonism to nicotine by C6, (c) antagonism of acetylcholine by hyoscine, and (d) antagonism of 5-HT by methysergide. Time trace, I min.

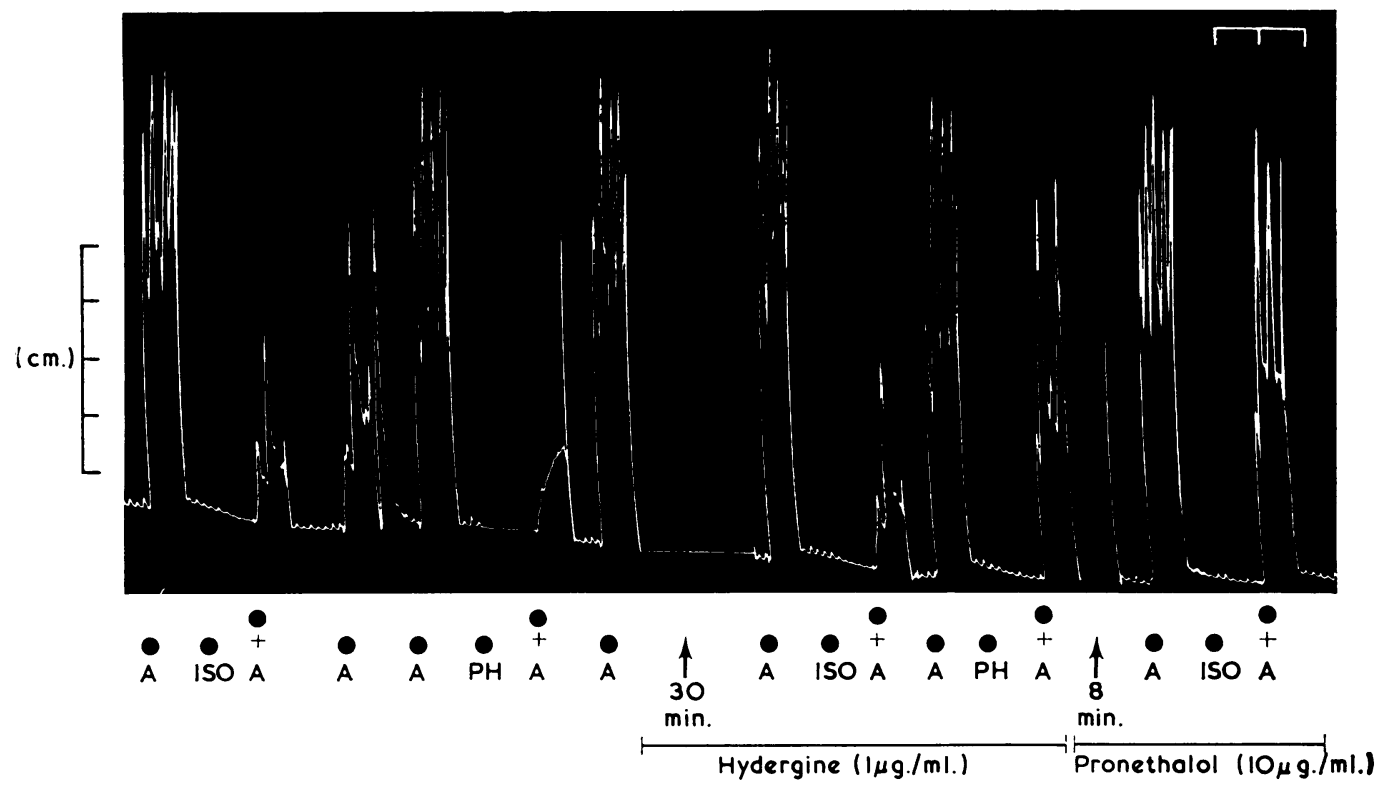

FIG. 4. The responses of an unusually reactive longitudinal muscle strip from the first part of the duodenum to acetyl choline $(A, 0.5 \mu \mathrm{g} . / \mathrm{ml}$.), the $\beta$-adrenergic receptor stimulant isoprenaline (ISO, $0 \cdot 2 \mu \mathrm{g} . / \mathrm{ml}$.) and the $\alpha$-adrenergic receptor stimulant phenylephrine $(\mathrm{PH}, 20 \mathrm{\mu g} . / \mathrm{ml}$.). The $\alpha$-adrenergic receptor blocking drug Hydergine antagonises phenylephrine but not isoprenaline. The $\beta$-adrenergic receptor antagonist pronethalol prevents the effect of isoprenaline. Time trace, 1 min. 
TABLE II

ESTIMATIONS OF THE 'INTRINSIC PARASYMPATHETIC AND SYMPATHETIC ACTIVITIES' OF DIFFERENT REGIONS OF THE HUMAN GASTROINTESTINAL TRACT, AND THEIR RELATIONSHIP TO (1) THE SIZE OF RESPONSE THAT ACETYLCHOLINE AND ADRENALINE CAN PRODUCE, AND (2) THE LOWEST DRUG CONCENTRATION THAT WILL PRODUCE A RESPONSE ${ }^{1}$

\begin{tabular}{|c|c|c|c|c|c|c|}
\hline Tissue & $\begin{array}{l}\text { 'Intrinsic Para- } \\
\text { sympathetic } \\
\text { Activity' }\end{array}$ & $\begin{array}{l}\text { Comparative } \\
\text { Ability to } \\
\text { Contract to } \\
\text { Acetylcholine }\end{array}$ & $\begin{array}{l}\text { Lowest Concen- } \\
\text { tration of Acetyl- } \\
\text { choline Required } \\
\text { to Contract } \\
\text { Tissue }(\mu \mathrm{g} . / \mathrm{ml} .)\end{array}$ & $\begin{array}{l}\text { 'Intrinsic } \\
\text { Sympathetic } \\
\text { Activity' }\end{array}$ & $\begin{array}{l}\text { Comparative } \\
\text { Ability to } \\
\text { Relax to } \\
\text { Adrenaline }\end{array}$ & $\begin{array}{l}\text { Lowest Concen- } \\
\text { tration of } \\
\text { Adrenaline } \\
\text { Required to } \\
\text { Relax Tissue } \\
(\mu \mathrm{g} . / \mathrm{ml} .)\end{array}$ \\
\hline Gastric body & + & + & $0 \cdot 1-0.8$ & + & + & $0.02-1$ \\
\hline Antrum & + & ++ & $0.05-0.8$ & + & + & $0.02-1$ \\
\hline $\begin{array}{l}\text { Duodenum } \\
\text { (first part) }\end{array}$ & 0 & + & $0 \cdot 1-2$ & + & + & $0.02-1$ \\
\hline $\begin{array}{l}\text { Duodenum } \\
\text { (second and } \\
\text { third parts) }\end{array}$ & $+t$ & ++ & $0 \cdot 01-1$ & + & ++ & $0.02-1$ \\
\hline Jejunum & +++ & $++t$ & $0.01-0.2$ & + & ++ & $0 \cdot 02-1$ \\
\hline $\begin{array}{l}\text { Colon } \\
\text { 'An arbitrary } \\
\text { it is often diffi }\end{array}$ & $\begin{array}{c}+ \\
\text { are of each of }\end{array}$ & ++ & 0.01-2 & $\begin{array}{c}++++ \\
\text { f signs. }\end{array}$ & +++ & $\begin{array}{c}0.02-1 \\
\text { y approximate }\end{array}$ \\
\hline
\end{tabular}

Of great interest are the effects of pharmacologically active substances which occur naturally in the gut wall. Of these, acetylcholine, sympathomimetic amines, histamine, and 5-HT have been studied in an attempt to evaluate their role in motility of the human gastrointestinal tract.

In this respect, a naturally occurring substance can only be accepted as a specific local chemostimulator if several criteria are fulfilled. For example, the substance must be stored near to the effector cells, and must be released during normal activity. The effect of the substance injected under suitable conditions must mimic physiological activity and both the drug-induced and the normal responses should be inhibited or potentiated similarly by specific drugs. The force of the evidence that a substance is a specific local chemostimulator lies in the conjunction of these criteria.

THE MOTOR FUNCTION OF PHARMACOLOGICALLY ACTIVE SUBSTANCES IN THE GUT WALL Each substance is discussed separately.

Acetylcholine Acetylcholine satisfies the above criteria and is the specific chemostimulator at ganglionic synapses and at parasympathetic postganglionic nerve endings. It contracts muscle strips from all parts of the gut. There are, however, regional differences not only in sensitivity to acetylcholine but in the ability of the muscle to contract. The stomach, the first part of the duodenum, and to some extent the colon, are less sensitive and give relatively small contractions even to large doses of acetylcholine. The distal part of the duodenum and the rest of the small bowel are more sensitive and respond with relatively large contractions (Table II).

Noradrenaline and adrenaline These substances are chemical transmitters at most post-ganglionic sympathetic nerve endings. They relax all muscle strips with two exceptions: these are the cardiac and ileocaecal sphincters. Unlike acetylcholine there appears to be little regional difference in sensitivity, but the ability of different regions to relax to noradrenaline and adrenaline varies. For example, adrenaline causes small relaxations of gastric body and large relaxations of colon (Table II). The responses to adrenaline are partly blocked by either Hydergine or pronethalol, but together these adrenergic receptor antagonists completely prevent relaxation. Thus in man there are two types of adrenergic receptors ( $\alpha$ and $\beta$ ) in the gut wall, both of which cause relaxation when stimulated. In contrast, stimulation of the $a$-receptors in the cardiac and ileocaecal sphincters causes contraction (Ellis, Kauntze, and Trounce, 1960; Gazet and Jarrett, 1964).

Histamine The response to this substance varies in different parts of the alimentary tract. Histamine has little effect on the stomach and proximal duodenum, but produces large contractions of distal duodenum and jejunum. It has a variable effect on ileum and colon, but the contractile effect predominates (Table III). The responses are abolished by mepyramine but unaffected by ganglion blockade, hyoscine, or anti-adrenaline drugs. It therefore appears to act directly on the muscle and not through nerves. 
TABLE III

RESPONSE OF DIFFERENT REGIONS OF THE HUMAN GASIROINTESTINAL TRACT TO HISTAMINE AND 5-HT

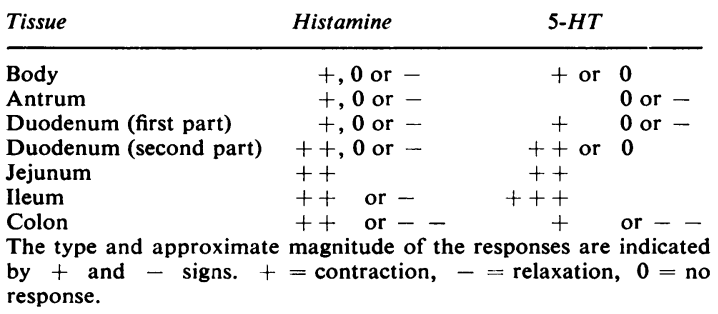

We must now consider the evidence for histamine as a specific local chemostimulator in motility. It is stored mainly in the mucosa (Douglas, Feldberg, Paton, and Schachter, 1951; Murray and Wyllie, 1964), and there is little in the muscle layer. There is no evidence that histamine release is related to nervous activity (Paton and Vane, 1963), although it can be released following mechanical deformation of the gut wall either during contraction or stretching. The evidence is therefore that stores of histamine are remote from the muscle, that histamine has variable effects on the muscle and that its release is not associated with nervous activity. Thus, it seems unlikely that histamine plays a significant role in the physiology of normal gastrointestinal motility. This conclusion is supported by the fact that antihistamines only occasionally alter bowel activity and may result in either diarrhoea or constipation (Goodman and Gillman, 1955).

5-Hydroxytryptamine The pattern of 5-HT activity on gastrointestinal strips is similar to that of histamine. It has little effect on stomach or proximal duodenum but distal duodenum, jejunum, and ileum contract vigorously. It either relaxes or contracts longitudinal colonic muscle but only relaxes the circular colonic strips (Table III). Its effects are blocked by 5 -HT antagonists but not by drugs which act at other sites. Thus, its action appears to be directly on the muscle. As with histamine, it seems unlikely that 5 -HT is a specific local chemostimulator to motility. Most of the 5-HT is stored in the mucosa and is remote from the muscle (Feldberg and Toh, 1953; Murray and Wyllie, 1964). Its release is not associated with nervous activity, but it is liberated into the lumen following deformation of the gut wall (Bülbring and Crema, 1959; Paton and Vane, 1963; Bennett, Bucknell, and Dean, 1966). The conclusion that 5-HT is unlikely to be a specific local chemostimulator to motility is supported by the fact that alterations in bowel activity have not been reported in patients treated with the 5-HT antagonist methy- sergide (Southwell, Williams, and Mackenzie, 1964).

A possibility which has not been tested in the present investigations is that 5-HT lowers the threshold of the receptors for the peristaltic reflex as it does in the guinea-pig (Bülbring and Lin, 1958). Its situation superficially in the mucosa would te in accord with such a mechanism. On the other hand, this effect appears to be species dependent since 5-HT is unimportant for the peristaltic reflex in the rat (Boullin, 1964; Bennett et al., 1966).

The present work illustrates the contractile effect of 5-HT on the human small intestine in vitro. This agrees with the increased motility which 5-HT produces in vivo (Hendrix, Atkinson, Clifton, and Ingelfinger, 1957; Haverback and Davidson, 1958). It supports the evidence that the increased bowel motility and diarrhoea in the carcinoid syndrome is due, at least in part, to the direct action of circulating 5-HT on the muscle of the small intestine; its effect presumably summates with that of acetylcholine.

THE CONTROL OF SPHINCTER MOTILITY It is the generally held view (for example, Goodman and Gillman, 1955; Keele and Neil, 1965) that the sphincters of the gastrointestinal tract respond in the opposite way to the rest of the gut. It is said that parasympathetic stimulation relaxes the sphincters whereas adrenaline and sympathetic stimulation contract them. When one reviews the evidence, however, it is difficult to see how this general conclusion was reached. For example, the effects of drugs on sphincter motility in animals appears to vary with the species studied, and the results on the same species are sometimes contradictory (Elliott, 1905; Kuroda, 1916; Brown and McSwiney, 1926; Thomas, 1929; Hinrichsen and Ivy, 1931; Clark and Vane, 1961; Harichaux and Thouvenot, 1962; Gazet and Jarrett, 1964; Armitage and Dean, 1966). Experiments in vivo on the ileocaecal sphincter in man also produce contradictory results. White, Rainey, Monaghan, and Harris (1934) and Buirge (1944) found that adrenaline relaxed the ileocaecal sphincter, but Liotta, Zuppone, and Giffoniello (1957) found that adrenaline sometimes increased and sometimes decreased sphincteric tone.

The studies in vitro referred to here show more consistent results and clarify one aspect of the problem. The extracaecal terminal ileum is relaxed by sympathomimetic amines (Bennett, 1965) whereas part of the ileum within the caecum-the ileocaecal sphincter-is contracted (Gazet and Jarrett, 1964; Bennett, 1966). In addition, the ileocaecal sphincter is contracted by acetylcholine. The responses are similar to those of the human cardiac sphincter which is also contracted by both adrenaline 
and acetylcholine (Ellis et al., 1960). In contrast, the so-called pyloric sphincter behaves in the same way as the rest of the gut; it contracts to acetylcholine but relaxes to sympathomimetic amines (Bennett and Whitney, 1966).

When we examine the physiology of the gastrointestinal sphincters, the evidence is that the cardiac sphincter is normally closed (Atkinson, Edwards, Honour, and Rowlands, 1957). By contrast, the pylorus is normally open and is closed intermittently by peristaltic waves from the stomach (Atkinson et al., 1957; Armitage and Dean, 1963). In this way, the pylorus functions not as a sphincter but as a combined filter and pump. Thus both the pharmacology and the physiology of the sphincters are different.

The cardiac and ileocaecal sphincters are contracted by acetylcholine as well as by adrenaline. How then do they relax? Perhaps they are normally contracted, but relax when tonic stimuli to them cease; or they may be forced open by high pressure (Ingelfinger, 1958). Another possibility is that adrenaline contracts sphincters by acting on $\alpha$ receptors and can relax them by acting on $\beta$-receptors (Ellis et al., 1960; Gazet and Jarrett, 1964). On the other hand, relaxation may be caused by an unknown substance, or may be a property of the muscle itself and independent of chemical transmitters.

INTRINSIC INNERVATION OF THE GASTROINTESTINAL TRACT Motility of the gastrointestinal tract is controlled by intrinsic nerve plexuses and is influenced in addition by extrinsic nerves. In general the parasympathetic ganglia are in the intestinal wall, but the ganglia of the sympathetic system are some distance away from the gut. As a result, the strips of isolated tissue contained parasympathetic ganglia and post-ganglionic parasympathetic and sympathetic nerve endings. There is some evidence, however, that the bowel wall contains ganglia having adrenergic processes (Paton and Vane, 1963).

The contractions of muscle strips produced by DMPP and nicotine were potentiated by eserine and blocked by hyoscine and hexamethonium. They were therefore due to acetylcholine released by stimulation of parasympathetic nervous tissue. The relaxations produced by these drugs were blocked by adrenergic receptor antagonists and hexamethonium. They therefore appear to involve an adrenaline-like substance released from tissue stores of amines or from sympathetic nerve endings (Burn, Leach, Rand, and Thompson, 1959; Ferry, 1963). It is also possible, however, that the ganglion stimulants act either on intramural ganglion cells having adrenergic post-ganglionic processes (Paton and Vane, 1963), or on inhibitory neurones which may or may not be adrenergic (Burnstock, Campbell, and Rand, 1966).

For general purposes we can consider that DMPP and nicotine act on intrinsic cholinergic and adrenergic tissue. On this basis, the response of a muscle strip to these drugs depends on (a) the amount of intrinsic cholinergic and adrenergic tissue present, (b) the degree to which they are stimulated, and (c) the responsiveness of the muscle to the released transmitters; this includes both sensitivity and the size of response which can be obtained with the drugs. Thus a contraction represents the "intrinsic parasympathetic activity' and a relaxation represents 'intrinsic sympathetic activity'. The net effect of DMPP or nicotine in the absence of cholinergic or sympathetic antagonists is therefore the balance of the 'intrinsic parasympathetic and sympathetic activities'.

Throughout the gastrointestinal tract there are marked regional differences in 'intrinsic activities' (Table II). To consider the stomach first, DMPP and nicotine produced only small contractions or relaxations of muscle strips (Bennett and Whitney, 1966). It therefore appears that the gastric 'intrinsic parasympathetic and sympathetic activities' are weak. Both DMPP and nicotine had a slight relaxant effect on the first part of the duodenum, indicating a little 'intrinsic sympathetic activity'; no effective 'intrinsic parasympathetic activity' could be demonstrated. In contrast, the drugs were much more active on the second and third parts of the duodenum, and produced both contractions and relaxations. The occurrence of 'intrinsic parasympathetic activity' was even more marked in the jejunum (Whitney, 1965), and was so great that the small amount of 'intrinsic sympathetic activity' could be unmasked only by blocking the parasympathetic effect with hyoscine. Further down the gut, there is less 'intrinsic parasympathetic activity' and the 'intrinsic sympathetic activity' predominates. Thus the effects of DMPP and nicotine on the ileum were predominantly relaxant (Bennett, 1965), and in the colon these drugs always caused relaxation (Fishlock and Parks, 1963; Bucknell and Whitney, 1964). Recent work, however, has demonstrated the presence of 'intrinsic parasympathetic activity' in the colon (Bucknell, 1965; Wright and Shepherd, 1966).

These results indicate a powerful cholinergic drive in distal duodenum and jejunum, but not in stomach and colon. They are consistent with the high concentration of acetylcholine in the small intestine, and with the greater production of acetylcholine which occurs in this region compared with the stomach and colon (Youmans, 1949). 
What are the factors which comprise intrinsic activity'? One possibility is that there are regional differences in the sensitivity of intrinsic nerves to stimulation by DMPP and nicotine. It seems more likely, however, that differences in 'intrinsic activity' are due mainly to two factors: the responsiveness of the muscle to the released transmitters, and the amount of intrinsic nervous tissue present. The responsiveness of strips of gut to acetylcholine and adrenaline is shown in Table II. With acetylcholine there are often regional differences of responsiveness, both as regards sensitivity and the ability to contract. With adrenaline, too, there are often regional differences in the ability of the muscle to respond, although there is little apparent difference in sensitivity. As a result, it is not possible to estimate with precision the relative contributions which responsiveness and the amounts of intrinsic nervous tissue make to the total 'intrinsic activity'. Nevertheless, comparison of the responses of different segments of bowel does indicate regional variations of intrinsic innervation. This is most obvious in the jejunum and ileum where the responsiveness to added acetylcholine or adrenaline is similar, but the effects of DMPP and nicotine are quite different. Thus the different response of these two tissues to 'nerve stimulation' is apparently due to different amounts of 'intrinsic parasympathetic and sympathetic' nervous tissue. Similar variations in intrinsic innervation presumably occur throughout the rest of the gut.

RELATIONSHIP BETWEEN MOTILITY AND THE NERVOUS TISSUE WITHIN THE GASTROINTESTINAL TRACT The pattern of motility in man varies considerably in different regions of the gastrointestinal tract. We now know from studies in vitro that there are also regional differences in 'intrinsic parasympathetic and sympathetic activities'. We have attempted to correlate these phenomena and examine them in relation to the function of each part of the gut. In general, a predominance of 'intrinsic parasympathetic activity' occurs in a segment of bowel concerned with considerable motility, and a predominance of 'intrinsic sympathetic activity' is found in a less active segment.

The response of gastric body strips to DMPP and nicotine is small. This finding is consistent with the fact that the body of the stomach acts mainly as a receptacle which prepares food for its onward passage. The response of the antrum is similar, again indicating weak 'intrinsic parasympathetic and sympathetic activities'. This at first sight is surprising since the antrum is more active in vivo than the body and is capable of developing high pressures. Perhaps the absence of a powerful cholinergic drive means that antral motility is governed to a large extent by myogenic factors. High antral pressures occur when an advancing peristaltic wave closes off the antrum from the duodenum and a succeeding wave closes it off from the body (Armitage and Dean, 1963). Thus although the contractions of the antral muscle are not necessarily large, they are nevertheless powerful.

The intrinsic activity of the first part of the duodenum is almost entirely sympathetic. This agrees with the finding of Alvarez (1948) that the duodenal cap is rather immobile in vivo, and supports the idea that this segment is more akin to the stomach than to the intestine. It is interesting that both the stomach and proximal duodenum are relatively unreactive to the drugs studied, and that both are derived embryologically from the fore-gut.

In contrast, there is a powerful cholinergic drive from the dominant 'intrinsic parasympathetic activity' in the distal duodenum and especially in the jejunum. This correlates with a need for vigorous segmentation and peristalsis which facilitate the digestion and onward propulsion of contents. In the ileum there is greater 'intrinsic sympathetic activity' which might serve to slow propulsion. Thus absorption is given time to take place, and passage of contents into the large intestine is slowed.

One of the most striking features of the colon is the very considerable predominance of 'sympathetic' over 'intrinsic parasympathetic activity'. This correlates with the function of the colon as a reservoir, but it is less easy to understand how contents are transported. This is particularly so, since Connell (1962) has emphasized the apparent paradox that intracolonic pressures are diminished in diarrhoea and increased in constipation. Furthermore, rise of intraluminal pressure and propulsion of colonic contents are not related (Ritchie, Ardran, and Truelove, 1962). It may be that the relative immobility of the colon, with the consequently diminished resistance to onward progress, is an important factor in this transport. Whatever the explanation may be, it will have to take into account the striking predominance of 'intrinsic sympathetic activity' found in strips of colon.

\section{SUMMARY}

A pharmacological study of strips of isolated human gastrointestinal tract is reported. The results include an investigation of duodenal muscle and a comparison of muscle strips from the whole of the alimentary canal from the stomach to the colon. The drugs used included substances known to be involved specifically in gastrointestinal motility (acetylcholine and noradrenaline), and other substances occurring naturally in the bowel wall 
(histamine and 5-HT). In addition, the effect of stimulating the nervous tissue in the bowel wall with DMPP and nicotine was investigated.

Throughout the gastrointestinal tract there are often marked regional differences in both the ability to react to the drugs and in the type of effect produced.

As regards sphincters, the pylorus resembles the rest of the gut in its response to drugs: acetylcholine causes a contraction and adrenaline a relaxation. In contrast, the cardiac and ileocaecal sphincters are pharmacologically distinct: both acetylcholine and adrenaline cause contraction.

Stimulation of the nervous tissue in the gut wall by DMPP or nicotine may cause either contraction or relaxation. The type and degree of response varies in different regions and depends mainly on the amounts of cholinergic and adrenergic nervous tissue present and on the responsiveness of the muscle to released transmitters. A contraction represents 'intrinsic parasympathetic activity' and a relaxation represents 'intrinsic sympathetic activity'.

The stomach and proximal duodenum have little 'intrinsic nervous activity'. In contrast distal duodenum, and in particular, jejunum, have a dominant cholinergic drive. More distally in the ileum and especially in the colon, however, the dominant influence is the 'intrinsic sympathetic activity'. An attempt has been made to correlate these findings with the functions of different regions of the gastrointestinal tract.

We are very grateful to Professor J. G. Murray and our other colleagues for their interest and help, and for making available specimens of tissue. We thank the Medical Research Council for a grant to one of us (B.W.).

\section{REFERENCES}

Alvarez, W. C. (1948). Introduction to Gastroenterology. 4th ed., p. 440. Hoeber, New York.

Armitage, A. K., and Dean, A. C. B. (1963). Function of the pylorus and pyloric antrum in gastric emptying. Gut 4, 174-178.

,$--(1966)$. The effects of pressure and pharmacologically active substances on gastric peristalsis in a transmurally stimulated rat stomach-duodenum preparation. J. Physiol. (Lond.), 182, 42-56.

Atkinson, M., Edwards, D. A. W., Honour, A. J., and Rowlands E. N. (1957). Comparison of cardiac and pyloric sphincters. Lancet, 2, 918-922.

Bennett, A. (1965). A pharmacological investigation of human isolated ileum. Nature (Lond.), 208, 1289-1291.

- (1966). Unpublished observations.

- Bucknell, A., and Dean, A. C. B. (1966). The release of 5hydroxytryptamine from the rat stomach in vitro. J. Physiol. (Lond.), 182, 57-65.

- , and Whitney, B. (1966). A pharmacological investigation of human isolated stomach. Brit. J. Pharmacol (In press).

Boullin, D. J. (1964). Observations on the significance of 5-hydroxytryptamine in relation to the peristaltic reflex of the rat. Brit. J. Pharmacol., 23, 14-33.

Brown, G. L., and McSwiney, B. A. (1926). Reaction to drugs of strips of the rabbit's gastric musculature. J. Physiol. (Lond.), 61, 261-267.
Bucknell, A. (1965). Personal communication.

- , and Whitney, B. (1964). A preliminary investigation of the pharmacology of the human isolated taenia coli preparation. Brit. J. Pharmacol., 23, 164-175.

Buirge, R. E. (1944). Experimental observations on the ileocecal valve. Surgery, 16, 356-369.

Bülbring, E., and Crema, A. (1959). The release of 5-hydroxytryptamine in relation to pressure exerted on the intestinal mucosa. J. Physiol. (Lond.), 146, 18-28.

- , and Lin, R. C. Y. (1958). The effect of intraluminal application of 5-hydroxytryptamine and 5-hydroxytryptophan on peristalsis; the local production of 5-HT and its release in relation to intraluminal pressure and propulsive activity. Ibid., 140, 381-407.

Burn, J. H., Leach, E. H., Rand, M. J., and Thompson, J. W. (1959). Peripheral effects of nicotine and acetylcholine resembling those of sympathetic stimulation. Ibid., 148, 332-352.

Burnstock, G., Campbell, G., and Rand, M. J. (1966). The inhibitory innervation of the taenia of the guinea-pig caecum. Ibid., 182, 504-526.

Clarke, C. G. and Vane, J. R. (1961). The cardiac sphincter in the cat. Gut, 2, 252-262.

Connell, A. M. (1962). The motility of the pelvic colon. Part II. Paradoxical motility in diarrhoea and constipation. Gut, 3 , 342-348.

Douglas, W. W., Feldberg, W., Paton, W. D. M., and Schachter, M. (1951). Distribution of histamine and substance $P$ in the wall of the dog's digestive tract. J. Physiol. (Lond.), 115, 163-176.

Elliott, T. R. (1905). The action of adrenalin. Ibid., 32, 401-467.

Ellis, F. G., Kauntze, R., Nightingale, A., and Trounce, J. R. (1960). Further studies in achalasia of the cardia. Quart. J. Med., 29, 305-312.

$\longrightarrow$, and Trounce, J. R. (1960). The innervation of the cardia and lower oesophagus in man. Brit. J. Surg., 47, 466-472.

Feldberg, W., and Toh, C. C. (1953). Distribution of 5-hydroxytryptamine (serotonin, enteramine) in the wall of the digestive tract. J. Physiol. (Lond.), 119, 352-362.

Ferry, C. B. (1963). The sympathomimetic effect of acetylcholine on the spleen of the cat. Ibid., 167, 487-504.

Fishlock, D. J., and Parks, A. G., (1963). A study of human colonic muscle in vitro. Brit. med. J., 2, 666-667.

$\longrightarrow,-$, and Dewell, J. V. (1965). Action of 5-hydroxytryptamine on the human stomach, duodenum and jejunum in vitro. Gut, 6, 338-342.

Gazet, J. C., and Jarrett, R. J. (1964). The ileocaeco-colic sphincter. Studies in vitro in man, monkey, cat, and dog. Brit. J. Surg., 51, 368-370.

Goodman, L. S., and Gillman, A. (1955). The Pharmacological Basis of Therapeutics, 2nd ed., pp. 490, 549. Macmillan, New York.

Graham, J. D. P. (1949). The effect of drugs on the motility of isolated strips of human stomach muscle. J. Pharm. Pharmacol., 1, 95-102.

Haverback, B. J., and Davidson, J. D. (1958). Serotonin and the gastrointestinal tract. Gastroenterology, 35, 570-578.

Hendrix, T. R., Atkinson, M., Clifton, J. A., and Ingelfinger, F. J. (1957). The effect of 5-hydroxytryptamine on intestinal motor function in man. Amer. J. Med., 23, 886-893.

Harichaux, P., and Thouvenot, J. (1962). Action des catécholamines sur la periodicité de l'evacuation pylorique chez le rat et la souris. C. R. Soc. Biol. (Paris), 156, 1141-1144.

Hinrichsen, J., and Ivy, A. C. (1931). Studies on the ileo-cecal sphincter of the dog. Amer. J. Physiol., 96, 494-507.

Ingelfinger, F. J. (1958). Esophageal motility. Physiol. Rev., 38, 533-584.

Kuroda, M. (1916). Observations of the effects of drugs on the ileocolic sphincter. J. Pharmacol. exp. Therap., 9, 187-195.

Keele, C. A. and Neil, E. (1965). Samson Wright's Applied Physiology, 11 th ed., pp. 336-337, Oxford University Press, London.

Liotta, D., Zuppone, V., and Giffoniello, A. H. (1957). Estudios sobre la motilidad y la farmacología del esfínter ileocecal v del ileon terminal en el hombre. Pren. méd. argent., 44, 30933096.

Murray, J. G., and Wyllie, J. H. (1964). Distribution of histamine, 5-hydroxytryptamine and other pharmacologically active substances in the human stomach. Gut, 5, 530-536.

Paton, W. D. M., and Vane, J. R. (1963). An analysis of the responses of the isolated stomach to electrical stimulation and to drugs. J. Physiol. (Lond.), 165, 10-46. 
Ritchie, J. A., Ardran, G. M., and Truelove, S. C. (1962). Motor activity of the sigmoid colon of humans. A combined study by intraluminal pressure recording and cineradiography. Gastroenterology, 43, 642-668.

Southwell, N., Williams, J. D., and Mackenzie, I. (1964). Methysergide in the prophylaxis of migraine. Lancet, 1, 523-524.

Thomas, J. E. (1929). A further study of the nervous control of the pyloric sphincter. Amer. J. Physiol., 88, 498-518.

Trounce, J. R., Deuchar, D. C., Kauntze, R., and Thomas, G. A. (1957). Studies in achalasia of the cardia. Quart. J. Med., 26, 433-443.

_ and Nightingale, A. (1960). Studies in Hirschsprung's disease. Arch. Dis. Childh., 35, 373-377.

Walder, D. N. (1953). The muscularis mucosae of the human stomach. J. Physiol. (Lond.), 120, 365-372.
White, H. L., Rainey, W. R., Monaghan, B., and Harris, A. S. (1934). Observations on the nervous control of the ileocaecal sphincter and on intestinal movements in an unanaesthetised human subject. Amer. J. Physiol., 108, 449-457.

Whitney, B. (1965). A preliminary investigation of the pharmacology of longitudinal muscle strips from human isolated jejunum. J. Pharm. Pharmacol., 17, 465-473.

Wright, P. G., and Shepherd, J. J. (1966). Some observations on the response of normal human sigmoid colon to drugs in vitro. Gut, 7, 41-51.

Youmans, W. B. (1949). Nervous and Neurohumoral Regulation of Intestinal Motility, pp. 87-88. Interscience Publishers. New York. 